\title{
Idiosyncratic effects of protection in a remote marine reserve
}

\author{
Simonetta Fraschetti*, Stanislao Bevilacqua, Giuseppe Guarnieri, Antonio Terlizzi
}

Dipartimento di Scienze e Tecnologie Biologiche ed Ambientali, Università del Salento, CoNISMa, 73100 Lecce, Italy

\begin{abstract}
A 10 yr study was carried out in the Tremiti Archipelago, a multiple-use Marine Protected Area (MPA) several miles off the mainland (South Adriatic, Italy), with a very small and isolated no-take area established in 1989 and characterized by limited enforcement. Patterns of variation in benthic assemblages along the intertidal rocky shores and in the rocky subtidal inside and outside the no-take area were examined between 2001 and 2010. Remarkable changes in the intertidal assemblages were detected within the no-take area, with an increase of Cystoseira canopies and the development of more diversified understory assemblages through time. Signs of regression in Cystoseira were documented in unprotected control areas. Conversely, $<20$ yr after the MPA designation, bare rock and patches of crustose coralline algae characterized subtidal assemblages in the no-take area. Increasing spatial heterogeneity of both intertidal and subtidal assemblages, probably representing an early warning of increasing human pressure, was also assessed. Data on primary production showed significantly higher values in the control areas than in the no-take area, with increasing values over time, indicating that the observed patterns are triggered by a combination of different drivers. Our results suggest that: (1) the effects of protection over benthic assemblages greatly depend on the habitats considered, which in turn, respond differently to specific human pressures occurring within and outside the reserve. A careful analysis of the distribution and intensity of all the activities allowed within multiple-use MPAs is critical for improving the effectiveness of conservation actions. (2) Isolation per se does not guarantee exclusion from human activities. In the presence of low enforcement, isolation may play a limited role in mitigating human pressures on benthic assemblages and may impair the connectivity of reserve networks.
\end{abstract}

KEY WORDS: Marine Protected Areas - Human pressures · Spatio-temporal heterogeneity · Marine habitats $\cdot$ Rocky benthic assemblages $\cdot$ Recovery

\section{INTRODUCTION}

Oceans are increasingly threatened worldwide: only few areas are subject to limited human pressures, whereas most are exposed to multiple and possibly interacting sources of stress (Halpern et al. 2008, Claudet \& Fraschetti 2010). In this context, Marine Protected Areas (MPAs) are considered key tools for ocean conservation strategies (Lester et al. 2009), playing a major role in reducing cumulative impacts without compromising social and economic development, especially in coastal areas where fishing and fishing-related impacts are the main threats (Worm et al. 2006, Jennings 2009, Halpern et al. 2010).

Several studies have evaluated the consequences of protection regimes, showing that marine no-take reserves, if properly designed and managed, can lead to direct ecological effects with significant increases in fish density, size, biomass and richness (e.g. CIESM 1999, Côté et al. 2001, Halpern \& Warner 2002, Gell \& Roberts 2003, Halpern 2003, Palumbi 2004, Micheli et al. 2004, Claudet et al. 2011). At both temperate and tropical latitudes, notake reserves can also positively affect the recovery 
trajectories of disturbed habitats and assemblages, stressing the critical role of protection in the mitigation of human impacts (Bevilacqua et al. 2006, Guidetti et al. 2008, Lester et al. 2009, Libralato et al. 2010, Mumby \& Harborne 2010). Attempts to generalize the ecological effects of MPAs have failed, however, since they can be extremely variable both in magnitude and direction (Frank et al. 2006, Shears et al. 2008, Lester et al. 2009, Claudet et al. 2010, Clemente et al. 2011). The combination of reserve features (e.g. size, zoning, time span from the institution, types of habitats included), context (e.g. location, conservation goals, socio-economic framework, compliance, enforcement, stressors outside the MPA), life history and ecological traits of protected species (Jennings 2000, Mosqueira et al. 2000, Côté et al. 2001, Micheli et al. 2004, Kaiser 2005, Claudet et al. 2008) can be responsible for this heterogeneity.

In contrast to no-take reserves, multiple-use MPAs rarely show large protection effects: they can confer some benefits over open-access areas, but, since recreational and commercial fishing are allowed, a significant increase in fishing effort has often been shown in the presence of partial protection, nullifying ecological benefits (Claudet et al. 2008). Additionally, in partially protected areas, various nonextractive uses, such as recreational and tourism activities, are not regulated in space and intensity, potentially affecting the overall environmental conditions (Parravicini et al. 2012).

Although both multiple-use MPAs and no-take reserves could indirectly mitigate human impacts by increasing the resilience of protected systems (Bellwood et al. 2004, Hughes et al. 2005), they cannot directly cope with many external stressors, such as terrestrial pollution, spread of pathogens, climate change and marine invasive species (Halpern et al. 2008, Mora \& Sale 2011, Terlizzi et al. 2011, 2012) and they are most useful when embedded into broader, multisector management plans (Fraschetti et al. 2011).

A network of MPAs as part of an integrated package of management approaches is considered a more effective strategy to significantly decrease cumulative impacts on coastal systems. The key role of a network to provide important links to maintain ecosystem processes and connectivity has been emphasized during the last decade, while the utility of single, isolated reserves is increasingly questioned (McLeod et al. 2009). A single reserve may play an important role in locally enhancing or stabilizing adult marine populations and assemblages. But if the reserve is too small, persistence of populations and assemblages may require input from surrounding areas (Gaines et al. 2010) and pressures can easily have detrimental effects inside its borders (Allison et al. 2003). This issue is exacerbated in insular assemblages, often considered unique due to unpredictable patterns of colonization/extinction, depending on the distance from other sources of colonists and/or on the size of islands (MacArthur \& Wilson 1967, Benedetti-Cecchi et al. 2003).

Single, isolated and small MPAs are still commonplace worldwide (Wood et al. 2008), and demonstration of effective networks is still very scarce. Even though the total ocean area protected has risen by $>150 \%$ since 2003 (Spalding et al. 2008), the recent increase has been driven by multiple new designations in a process that still appears more random than systematic (Wood et al. 2008). In this respect, the Mediterranean Sea represents an emblematic example. Each country has its own guidelines, and there is no combined legislation or criteria for the establishment of MPAs. Socio-economical constraints together with the fragmented geopolitical scenario characterizing the basin still lead to the institution of single, small and uncoordinated MPAs, with 35\% represented by islands (www.medpan.org). Their planning is often based on little common sense, with poor evaluations and little scientific justification for site selection. This approach, in many cases, leads to inappropriate design, so that as a result many habitats are unprotected, and spacing between protected sites is probably too wide to ensure larval exchange (Sala et al. 2002, Fraschetti et al. 2005). Moreover, there is evidence that management and/or enforcement is still not adequate in almost half of the Mediterranean MPAs and so-called 'paper parks' are still very common (Abdulla et al. 2008, Guidetti et al. 2008).

The lack of general conservation strategies coupled with ineffective management of MPAs prevents the reversal of habitat loss and degradation. As an example, on temperate coasts, there is increasing concern about the permanent replacement of perennial canopy-forming algae (i.e. structurally complex and highly productive habitats), both in the intertidal and in the subtidal, with opportunistic taxa such as filamentous turf-forming algae, other ephemeral seaweeds, mussels and urchin 'barrens' (i.e. comparatively simpler species assemblages). These regime shifts relate to the life-cycle traits of opportunistic species, allowing their persistence in human-dominated seascapes, and drivers and consequences of anthropogenic forcing have been widely documented (Perkol-Finkel \& Airoldi 2010): modified water quality (i.e. change in primary production, increasing nutrients, heavy metals and sediment loads) and overfish- 
ing are considered key drivers of these regime shifts triggering the loss of marine canopy-dominated habitats (Gorman \& Connell 2009).

Here, we investigated patterns of spatio-temporal variation in subtidal sessile assemblages and in assemblages associated with intertidal canopy-formers of a partially protected area compared with assemblages of a no-take reserve over a decade, in the Tremiti Archipelago, a remote MPA with limited enforcement. Our hypothesis was that even though the no-take reserve has limited enforcement, it can still play a role in protecting the ecosystem from human pressures due to its isolation. However, we anticipated that effects of protection greatly depend on the habitats and that, in the presence of limited regulation and compliance, isolation per se is likely to produce idiosyncratic outcomes in mitigating human impacts, according to habitat features and to the nature of pressures existing within and outside the MPA.

\section{MATERIALS AND METHODS}

\section{Study area}

The study was carried out in the Tremiti Archipelago $\left(42^{\circ} 07^{\prime} \mathrm{N}, 15^{\circ} 29^{\prime} \mathrm{E}\right)$, situated in the Adriatic Sea, about $22 \mathrm{~km}$ off the Gargano coast in the Apulia region, Italy (Fig. 1). The MPA was designated in 1989 and covers a surface of about 1466 ha. It is a multiple-use MPA formed by a group of 5 islands.

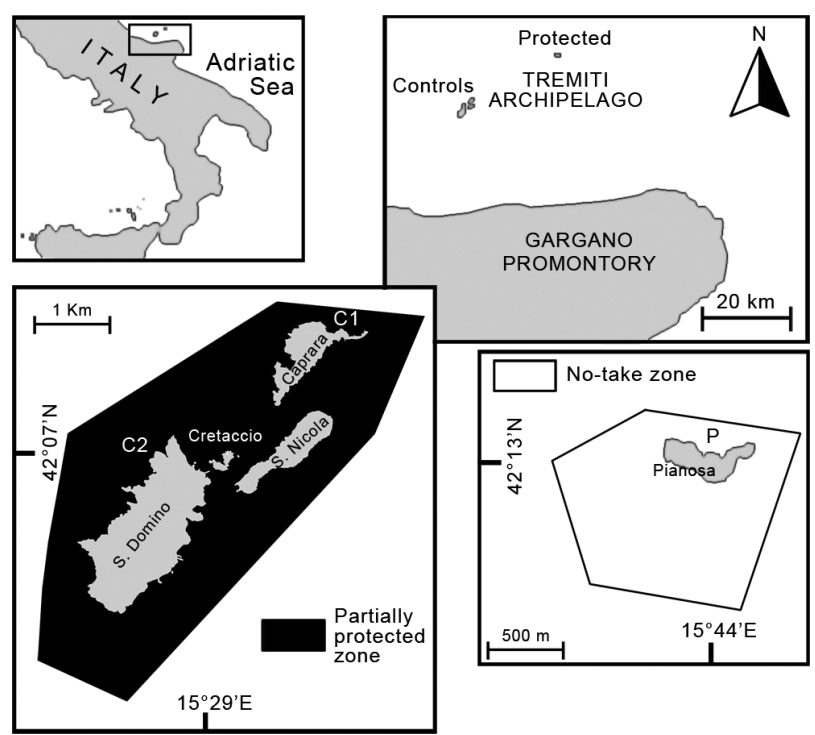

Fig. 1. Map of the study area showing the Marine Protected Area (MPA) gradient of protection together with sampling locations. P: no-take location; $\mathrm{C} 1$ and $\mathrm{C} 2$ : control locations in partially protected zone
Under Italian law, the MPA shows a gradient of restrictions (e.g. Villa et al. 2002), with areas with a partial protection regime located around the main group of islands in the Archipelago (i.e. S. Domino, S. Nicola, Cretaccio, Caprara). Within these areas most human activities (e.g. bathing, diving, boat traffic, recreational fishing) are allowed, although professional fishing is subjected to authorization. The notake area is confined to the uninhabited island of Pianosa, about $20 \mathrm{~km}$ from the other 4 islands. Here, all human activities are forbidden, except authorized scientific research.

Approximately 500 people represent the resident population within the Archipelago. However, due to the touristic usage of the whole area, the MPA is traditionally affected by a number of related human activities (e.g. diving, boat traffic and anchoring, sewage discharges) with overfishing considered one of the major threats (www.medpan.org). The implementation of an adequate management plan is still under development (Abdulla et al. 2008), and the persistence of poaching is still presumed, even within the no-take zone, due to the difficulties (e.g. lack of financial support) of the management body to ensure routine surveillance.

\section{Sampling design and data collection}

Sampling was carried out 5 times at 3 locations from 2001 to 2010 (May 2001, September 2002, September 2003, May 2006, July 2010) on sessile assemblages associated with both the Cystoseira canopy (mainly C. amentacea) of the rocky intertidal and the shallow rocky subtidal. One location corresponded to the no-take zone (P), and 2 locations were selected as control areas in the partially protected area (C1 and C2) (Fig. 1). Controls (Cs) were chosen at random from a set of possible locations, to provide comparable habitats to those occurring in the reserve (in terms of depth, type and slope of the substratum and wave exposure). Three sites (approximately 100 to $300 \mathrm{~m}$ apart from each other) were randomly sampled at each location. This is an ecological context in which testing for differences in the patterns of distribution of assemblages can be particularly challenging in view of the difficulty in selecting comparable control/reference locations. We acknowledge these limitations, and we cannot exclude that several processes relevant to assemblages of rocky substrate could operate differently at the different islands.

The understory assemblages of the Cystoseira canopy were sampled at each site. Ten $20 \times 20 \mathrm{~cm}$ 
randomly located quadrats were sampled to estimate the in situ abundance of sessile organisms. Visual estimates were made by dividing each quadrat into twenty-five $4 \times 4 \mathrm{~cm}$ sub-quadrats to help counting. The percentage cover was evaluated after the visual estimation of the cover of the Cystoseira canopy following its removal. The total number of taxa and their relative abundance were assessed giving a score from 0 (absence) to 4 (totally covered) to each taxon present on each sub-quadrat and adding up these values over the 25 sub-quadrats (Meese \& Tomich 1992, Dethier et al. 1993). Final values were expressed as percentages. Organisms that were not easily identifiable at species level were collapsed into higher taxonomic groups or into morphological groups (Steneck \& Dethier 1994; see Table 1 present study for more details). Mobile animals (e.g. gastropods, polychaetes, peracarid crustaceans) were not considered in the analyses.
In the shallow subtidal, assemblages at 4 to $7 \mathrm{~m}$ depth were sampled photographically using a Nikonos $\mathrm{V}$ underwater camera, $28 \mathrm{~mm}$ focal length, closeup macro-system and 2 SB 105-Nikon electronic strobes. To prevent problems due to loss of samples or blurred photographs, 13 randomly located quadrats of $16 \times 23 \mathrm{~cm}$ were photographed at each site and 10 of them were used in subsequent laboratory analyses. The slides were analysed under magnification, and percentage cover values of each taxon were estimated according to the procedure described above for the intertidal assemblages. Destructive samples were collected for later identification of organisms present in the slides. Organisms not identified at species level were collapsed into higher taxonomic groups or into morphological groups. Full taxonomic details are reported in Table 1.

Since the differences in specific human activities between the main group of islands compared with

Table 1. List of taxa found in both habitats. CU: Cystoseira understory (intertidal); S: subtidal. Abbreviations used in canonical analysis of principal coordinates are given in brackets

\begin{tabular}{|c|c|c|c|}
\hline Habitat & Taxon & Habitat & Taxon \\
\hline CU/S & Articulated corallines [AC] & CU & Encrusting sponges undefined [ES] \\
\hline CU/S & Acetabularia acetabulum [Ace] & $\mathrm{CU}$ & Erect bryozoans \\
\hline CU/S & Actinians [Att] & $\mathrm{S}$ & Flabellia petiolata \\
\hline CU/S & Amphiroa rigida [Amp] & CU/S & Gastrochaena dubia [Gdu] \\
\hline $\mathrm{CU} / \mathrm{S}$ & Anadyomene stellata & $\mathrm{S}$ & Gelidiales \\
\hline $\mathrm{S}$ & Ascidia mentula & CU/S & Green filamentous algae [GFA] \\
\hline CU & Balanidae [Bal] & $\mathrm{CU} / \mathrm{S}$ & Halimeda tuna $[\mathrm{Htu}]$ \\
\hline $\mathrm{CU} / \mathrm{S}$ & Balanophyllia europea [Beu] & $\mathrm{S}$ & Hemimycale sp. \\
\hline CU & Bivalves [Biv] & $\mathrm{CU} / \mathrm{S}$ & Hydrozoa [Hyd] \\
\hline $\mathrm{S}$ & Botryocladia sp. & $\mathrm{CU} / \mathrm{S}$ & Hypnea musciformis [Hyp] \\
\hline $\mathrm{S}$ & Caryophillia sp. & $\mathrm{CU} / \mathrm{S}$ & Ircinia sp. \\
\hline $\mathrm{CU}$ & Ceramiales [Cer] & $\mathrm{CU} / \mathrm{S}$ & Laurencia complex [Lau] \\
\hline CU/S & Coarsely branched algae & $\mathrm{CU} / \mathrm{S}$ & Liagora viscida \\
\hline CU/S & Champia sp. [Cha] & $\mathrm{S}$ & Lithophaga lithophaga \\
\hline $\mathrm{S}$ & Chondrosia reniformis [Cho] & $\mathrm{S}$ & Massive dark sponges [MDS] \\
\hline CU/S & Cirripeda [Cir] & $\mathrm{S}$ & Microcosmus sp. \\
\hline S & Cladocora cespitosa & $\mathrm{CU} / \mathrm{S}$ & Padina pavonica [Pad] \\
\hline $\mathrm{CU}$ & Clavularidae [Cla] & $\mathrm{S}$ & Palmophyllum crassum \\
\hline $\mathrm{CU} / \mathrm{S}$ & Cliona sp. [Cli] & $\mathrm{S}$ & Petrosia ficifromis \\
\hline $\mathrm{CU}$ & Cliona celata & CU/S & Peyssonnelia spp. [Pey] \\
\hline $\mathrm{S}$ & Codium bursa [Cbu] & $\mathrm{S}$ & Phallusia fumigata \\
\hline $\mathrm{S}$ & Codium effusum & $\mathrm{CU}$ & Rivularia sp. \\
\hline $\mathrm{CU}$ & Colpomenia sinuosa & $\mathrm{CU} / \mathrm{S}$ & Serpuloidea [Ser] \\
\hline CU/S & Corallina sp. [Cor] & $\mathrm{S}$ & Sphaerococcus spp. \\
\hline $\mathrm{CU} / \mathrm{S}$ & Cutleriales [Cut] & $\mathrm{S}$ & Spondylus sp. \\
\hline CU/S & Dark filamentous algae [DFA] & $\mathrm{CU} / \mathrm{S}$ & Stoloniferi \\
\hline CU/S & Dictyotales [Dic] & $\mathrm{S}$ & Stypocaulaceae [Sty] \\
\hline CU/S & Didemnidae [Did] & $\mathrm{S}$ & Terpios fugax \\
\hline $\mathrm{CU} / \mathrm{S}$ & Diplosoma listerianum [Dli] & $\mathrm{S}$ & Thin ramified bryozoans [TRB] \\
\hline $\mathrm{S}$ & Dumontiaceae & $\mathrm{S}$ & Tricleocarpa fragilis [Tri] \\
\hline $\mathrm{S}$ & Dysidea spp. & $\mathrm{CU} / \mathrm{S}$ & Thin tubular or sheet-like \\
\hline $\mathrm{CU} / \mathrm{S}$ & Encrusting bryozoans [EB] & $\mathrm{CU} / \mathrm{S}$ & Valonia macrophysa [Vma] \\
\hline $\mathrm{CU} / \mathrm{S}$ & Encrusting calcareous rhodophytes [ECR] & $\mathrm{CU} / \mathrm{S}$ & Vermetidae [Ver] \\
\hline $\mathrm{S}$ & Encrusting red sponges [ERS] & $\mathrm{CU} / \mathrm{S}$ & Wrangelia penicillata \\
\hline
\end{tabular}


the no-take zone (e.g. sewage discharge, visiting vessels) could influence the water quality of coastal waters, we analysed monthly averaged primary production (PP) from January 2003 to December 2010, obtained from satellite-derived data (http:// coastwatch.pfel.noaa.gov). Vertically integrated PP was calculated by applying the method of Behrenfeld \& Falkowski (1997) to the surface chlorophyll a concentration. Photosynthetically available radiation and sea-surface temperature (SST) were provided by the moderate-resolution imaging spectrometer (MODIS) carried aboard NASA's Aqua spacecraft. SST was derived from the Pathfinder Version 5 advanced very high resolution radiometer (AVHRR) data set (Casey et al. 2010). Time series data were extracted from monthly averages centred on the main group of islands and the no-take zone.

\section{Data analyses}

\section{Multivariate analyses}

Two separate distance-based permutational multivariate analyses of variance (PERMANOVA; Anderson 2001, McArdle \& Anderson 2001), one for each of the 2 investigated habitats, were performed to test for differences in benthic assemblages between $\mathrm{P}$ and $\mathrm{Cs}$ across time. The analyses were based on Bray-Curtis dissimilarities calculated on raw data, and each term was tested using 4999 random permutations. No transformation of data was applied because our hypothesis focused on the assemblage as it is and did not require changing the relative importance of rare or abundant taxa (McArdle \& Anderson 2004).

For both analyses, the experimental design consisted of 3 factors: Time ( $T, 5$ levels, random), Location ( $\mathrm{L}, 3$ levels, random, with 1 protected location and 2 control locations), Site (S[L], 3 levels, random, nested in L), with $n=10$. Because of the presence of a single no-take zone (P) and 2 control locations (Cs) the design was asymmetrical (Glasby 1997). Therefore, for the analyses, all sources of variation including the term $\mathrm{L}$ were partitioned into 2 components, namely the variability between the controls and the differences between P and Cs. Rocky assemblages of temperate systems feature strong seasonal fluctuations (Coma et al. 2000). The lack of random dates of sampling for each of the 5 times included in the design did not allow a proper separation between the within-time (i.e. the random effect of the short-term variability for each time) and the among-time (i.e. the fixed effect of long-term differences among times) variations. This prevented us from formally testing directional changes in assemblages through the years. The factor $\mathrm{T}$ was therefore considered random, as the relevant hypotheses concerned the differences between $\mathrm{P}$ and Cs and their consistency through the years. Appropriate denominators for $F$-ratios were identified from expected mean squares, and tests were constructed following the logic of asymmetrical designs (see Terlizzi et al. 2005 for details).

Non-metric multidimensional scaling ordination (nMDS) (Kruskal \& Wish 1978) of $\mathrm{T} \times \mathrm{L}$ centroids was plotted to visualize patterns of differences among locations through time. Centroids were obtained by calculating principal coordinates (PCO) on the basis of Bray-Curtis dissimilarity matrices among all pairs of sample units.

For both intertidal and shallow subtidal assemblages, 5 canonical analyses of principal coordinates (CAP; Anderson \& Robinson 2003, Anderson \& Willis 2003) were also performed for the $L$ term, calculating the distance matrix among replicates of the 3 locations separately for each sampling time. Distinctness among L groups was assessed using leave-one-out allocation success (Anderson \& Robinson 2003). Individual taxa that might be responsible for any group differences seen in the CAP plot were investigated by calculating product-moment correlations of original variables (taxa) with canonical axes (e.g. Anderson \& Willis 2003). These correlations of individual variables with the 2 canonical axes $\left(r^{1}\right.$ and $\left.r^{2}\right)$ were then represented as lines in the CAP plot. Taxa were included in the plot only if exceeding an arbitrarily chosen value of correlation (i.e. $\sqrt{r_{1}^{2}+r_{2}^{2}} \geq 0.3$ ).

Finally, to test for differences in the spatial heterogeneity of assemblages between $\mathrm{P}$ and $\mathrm{Cs}$, a permutational analysis of multivariate dispersion (PERMDISP; Anderson et al. 2006) at the scale of replicates and sites on the basis of Bray-Curtis dissimilarity was carried out for the factor $\mathrm{T} \times \mathrm{P}$ vs. Cs. This approach allowed comparisons of small-scale patchiness (among replicates) and within locations (among sites) in assemblage structure between $\mathrm{P}$ and Cs through time.

All analyses were performed using the computer program PRIMER V6 (Clarke \& Gorley 2006), including the add-on package PERMANOVA+ (Anderson et al. 2008).

\section{Univariate analyses}

For both intertidal and subtidal data sets, ANOVA was employed to test for differences in the total num- 
ber of taxa between $\mathrm{P}$ and Cs. ANOVA was also employed to test for differences in the percentage cover of canopy formed by Cystoseira spp. in the intertidal between $\mathrm{P}$ and Cs. The design for analyses was the same employed for PERMANOVA (see subsection above).

Temporal variability of assemblages was also assessed as a measure of community stability. ANOVA on multivariate estimates of temporal variability was also done for both intertidal and subtidal data sets. For each data set, values were analysed separately for each of the 9 sites (i.e. the 3 sites within $\mathrm{P}$ and the 6 sites in Cs) using PERMANOVA, obtaining pseudo-variance components associated with the factor $\mathrm{T}$. This allowed calculation of 9 multivariate estimates of temporal variability in assemblages. One-factor asymmetrical ANOVA was employed to test for differences in temporal variability between $\mathrm{P}$ and $\mathrm{Cs}$.

ANOVA was also used to test for differences in the PP between the notake zone and controls. The design for analysis consisted of 2 factors, T (8 levels, random) and L (2 levels, fixed, orthogonal).

\section{RESULTS}

In the intertidal, PERMANOVA showed that differences in assemblage structure between the reserve and the controls varied in time (see the $\mathrm{T} \times \mathrm{P}$ vs. Cs interaction in Table 2). A signif- icant $\mathrm{T} \times \mathrm{S}(\mathrm{L})$ interaction, indicating significant variability among sites not varying consistently in time, was also observed. With all the limits posed by considering the factor $\mathrm{T}$ as random (see 'Materials and methods'), the nMDS ordination (Fig. 2A) indicated progressive separation between the reserve and the control centroids from 2001 (T1) to 2010 (T5), suggesting a directional change in patterns of variation. This temporal trajectory was confirmed in CAP analysis of all times of sampling (see Fig. S1A in the supplement at www.int-res.com/articles/suppl/m466 p021.pdf), here reported for the sake of brevity

Table 2. Summary of PERMANOVA testing for the effect of protection on intertidal and subtidal benthic assemblages (see details in the 'Results'). Analyses were based on Bray-Curtis dissimilarities, and each test was performed using 4999 permutations of appropriate units. Significant p-values are given in bold. Terms already involved in significant higher order interactions were not analysed. T: Time; L: Location; S: Site; P: no-take locations; Cs: control locations

\begin{tabular}{|c|c|c|c|c|c|c|}
\hline \multirow{2}{*}{$\begin{array}{l}\text { Source } \\
\text { of variation }\end{array}$} & \multicolumn{3}{|c|}{ - Rocky intertidal } & \multicolumn{3}{|c|}{ Rocky subtidal } \\
\hline & MS & $F$ & $\mathrm{p}$ & MS & $F$ & $\mathrm{p}$ \\
\hline $\mathrm{T}$ & 49846 & & & 23026 & & \\
\hline $\mathrm{L}$ & 18861 & & & 137460 & & \\
\hline P vs. Cs & 24320 & & & 254296 & & \\
\hline Cs & 13402 & & & 20634 & & \\
\hline $\mathrm{S}(\mathrm{L})$ & 10559 & & & 7159.2 & & \\
\hline $\mathrm{S}(\mathrm{P})$ & 6445.5 & & & 6105 & & \\
\hline $\mathrm{S}(\mathrm{Cs})$ & 12616 & & & 7686.2 & & \\
\hline $\mathrm{T} \times \mathrm{L}$ & 11973 & 1.29 & 0.087 & 12908 & 1.85 & 0.0052 \\
\hline $\mathrm{T} \times \mathrm{P}$ vs. $\mathrm{Cs}$ & 14587.8 & 1.58 & 0.0334 & 13300.8 & 1.91 & 0.005 \\
\hline $\mathrm{T} \times \mathrm{Cs}$ & 9358.1 & 0.84 & 0.6966 & 12514 & 1.49 & 0.0766 \\
\hline $\mathrm{T} \times \mathrm{S}(\mathrm{L})$ & 9242.7 & 6.01 & 0.0002 & 6976.1 & 5.73 & 0.0002 \\
\hline $\mathrm{T} \times \mathrm{S}(\mathrm{P})$ & 5377.5 & 3.85 & 0.0002 & 4121.2 & 3.76 & 0.0002 \\
\hline $\mathrm{T} \times \mathrm{S}(\mathrm{Cs})$ & 11175 & 6.94 & 0.0002 & 8403.5 & 6.56 & 0.0002 \\
\hline Residuals & 1537.8 & & & 1218.4 & & \\
\hline Res. P & 1395.4 & & & 1095 & & \\
\hline Res. Cs & 1609 & & & 1280.1 & & \\
\hline
\end{tabular}

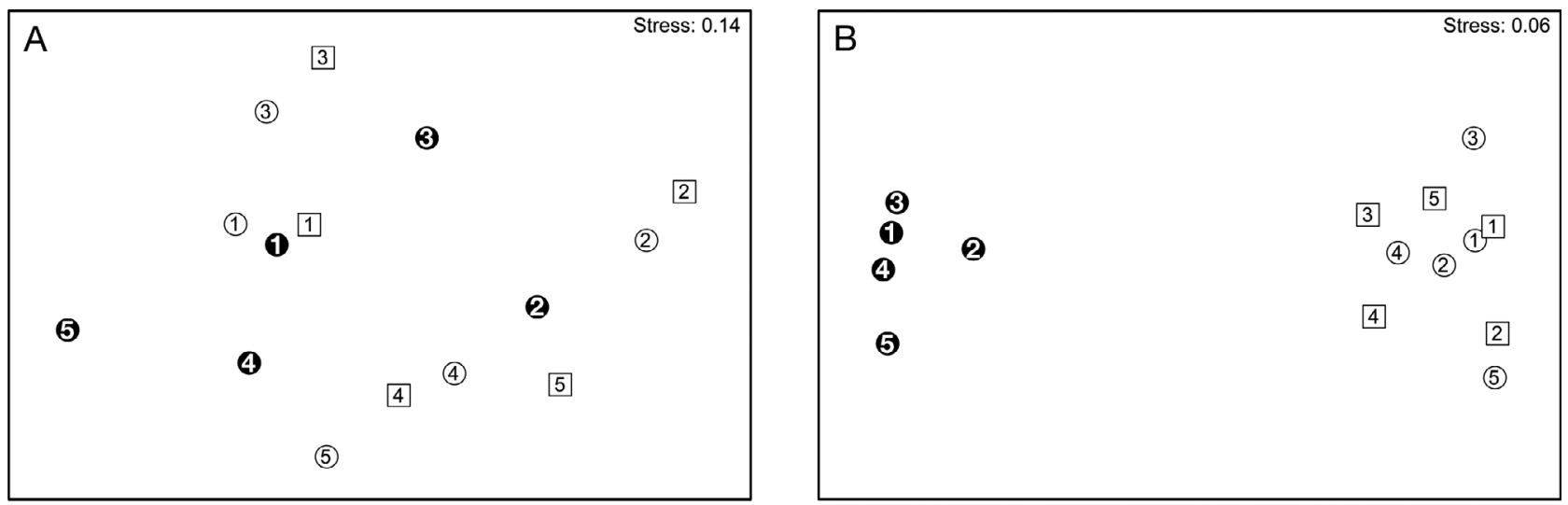

Fig. 2. Non-metric multidimensional scaling ordinations of Time $\times$ Location centroids based on Bray-Curtis dissimilarity measures for (A) intertidal and (B) subtidal assemblages. Black symbols: no-take locations; white symbols: control locations. The numbers from 1 to 5 inside each symbol indicate sampling times 
through the CAP plot of Time 1 and Time 5 (Fig. 3). Time 1 assemblages within the reserve area were indistinguishable from those characterizing the controls (Fig. 3A), whereas at Time 5, colonial ascidians (Didemnidae [Did], Diplosoma listerianum [Dli]) and other invertebrates (Actinians [Att], Clionidi [Cli], Hydroids [Hyd]) characterized assemblages within the no-take zone, whereas assemblages at controls were structurally dominated by turf-forming algae (Champia sp. [Cha], Laurencia complex [Lau], dark filamentous algae [DFA], Articulated Corallines [AC]) (Fig. 3A).
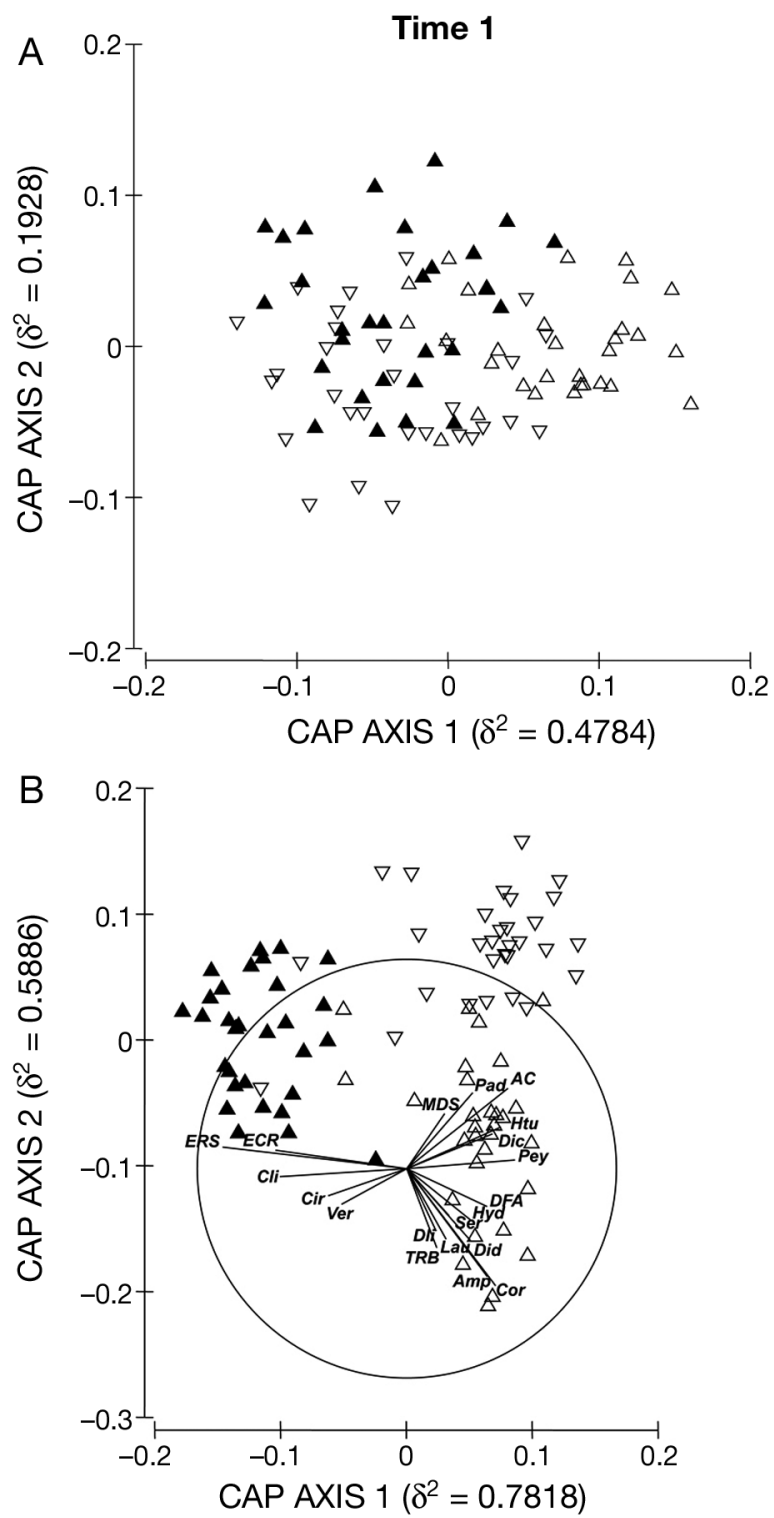

ANOVA on the total number of taxa showed significant temporal variability at the scale of sites only within controls. The analysis did not detect significant differences in the number of taxa between the no-take zone and control areas (Table 3, Fig. 4A). Furthermore, ANOVA of the percentage cover of Cystoseira spp. showed no significant differences between the reserve and the controls, although the $\mathrm{p}$-value of the $\mathrm{T} \times \mathrm{P}$ vs. Cs interaction was at the limit of significance (Table 3), suggesting the occurrence of changes in the cover of Cystoseira through time (Fig. 4C). A significant $\mathrm{T} \times \mathrm{S}(\mathrm{L})$ interaction was
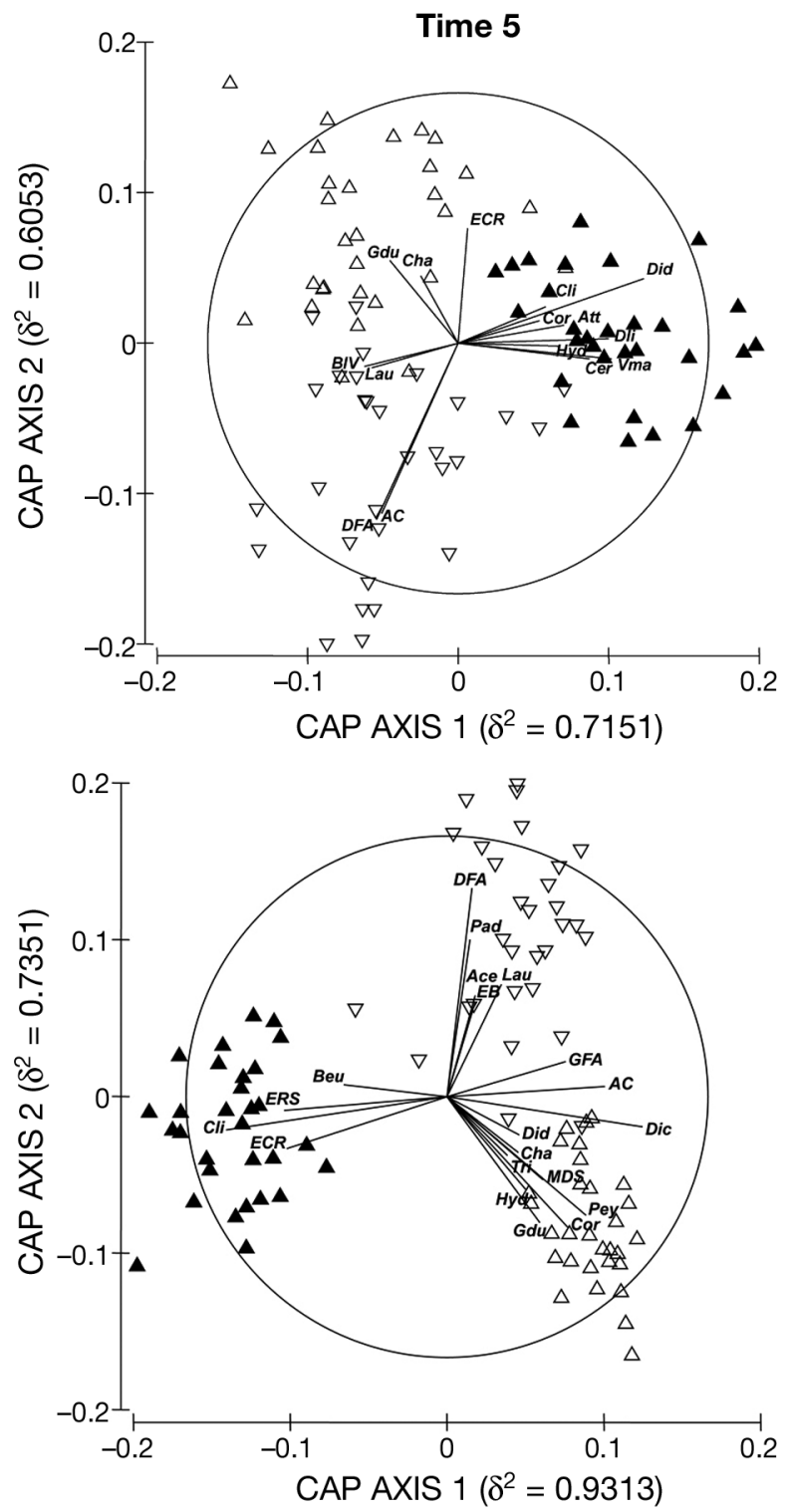

Fig. 3. Canonical analysis of principal coordinates (CAP) for the factor Locations based on the distance matrix of sampling units of (A) intertidal and (B) subtidal assemblages at Time 1 and Time 5. Individual taxa highly correlated with canonical axes are shown for both Times 1 and 5 in the subtidal, but only for Time 5 for the intertidal (see 'Results' for further details). Abbreviations for taxa used in CAP plots are given in Table 1. Black symbols: no-take locations; white symbols: control locations 
Table 3. Summary of ANOVA testing for the effect of protection on percent cover of Cystoseira spp. and on the total number of taxa in both habitats at each time of sampling. Significant $p$-values are given in bold. T: Time; L: Location;

S: Site; P: no-take locations; Cs: control locations

\begin{tabular}{|c|c|c|c|c|c|c|c|}
\hline \multirow[t]{2}{*}{$\begin{array}{l}\text { Source } \\
\text { of variation }\end{array}$} & \multirow[t]{2}{*}{ df } & \multicolumn{2}{|c|}{$\begin{array}{c}\text { Cystoseira } \\
\text { spp. }\end{array}$} & \multicolumn{2}{|c|}{$\begin{array}{c}\text { No. of } \\
\text { intertidal taxa }\end{array}$} & \multicolumn{2}{|c|}{$\begin{array}{c}\text { No. of } \\
\text { subtidal taxa }\end{array}$} \\
\hline & & $F$ & $\mathrm{p}$ & $F$ & $\mathrm{p}$ & $F$ & $\mathrm{p}$ \\
\hline $\mathrm{T}$ & 4 & 11.27 & 0.004 & 6.39 & 0.0116 & 1.55 & 0.2822 \\
\hline $\mathrm{L}$ & 2 & 2.01 & 0.1134 & 0.84 & 0.5704 & 10.95 & 0.0008 \\
\hline P vs. Cs & 1 & 0.06 & 0.8472 & 0.71 & 0.4082 & 33.95 & 0.0004 \\
\hline Cs & 1 & 7.94 & 0.0056 & 1.01 & 0.4334 & 2.1 & 0.1602 \\
\hline $\mathrm{S}(\mathrm{L})$ & 6 & 1.63 & 0.1724 & 1.32 & 0.2842 & 2.8 & 0.0304 \\
\hline $\mathrm{S}(\mathrm{P})$ & 2 & 2.04 & 0.1927 & 1.52 & 0.2758 & 10.16 & 0.0064 \\
\hline $\mathrm{S}(\mathrm{Cs})$ & 4 & 1.32 & 0.3114 & 1.3 & 0.3152 & 1.67 & 0.2074 \\
\hline $\mathrm{T} \times \mathrm{L}$ & 8 & 1.42 & 0.2428 & 0.75 & 0.6474 & 3.74 & 0.006 \\
\hline $\mathrm{T} \times \mathrm{P}$ vs. $\mathrm{Cs}$ & 4 & 2.63 & 0.05 & 1.14 & 0.3634 & 0.42 & 0.7881 \\
\hline $\mathrm{T} \times \mathrm{Cs}$ & 4 & 0.24 & 0.905 & 0.27 & 0.895 & 4.05 & 0.021 \\
\hline $\mathrm{T} \times \mathrm{S}(\mathrm{L})$ & 24 & 5.61 & 0.0002 & 4.27 & 0.0002 & 1.99 & 0.003 \\
\hline $\mathrm{T} \times \mathrm{S}(\mathrm{P})$ & 8 & 7.24 & 0.0001 & 1.29 & 0.2535 & 0.9 & 0.5158 \\
\hline $\mathrm{T} \times \mathrm{S}(\mathrm{Cs})$ & 16 & 4.79 & 0.0002 & 5.93 & 0.0002 & 2.44 & 0.002 \\
\hline Residuals & 405 & & & & & & \\
\hline Res. P & 135 & & & & & & \\
\hline Res. Cs & 270 & & & & & & \\
\hline
\end{tabular}

detected for the percentage cover of Cystoseira spp., indicating a significant temporal variation of amongsite variability in the abundance of these algae. No significant differences in patterns of multivariate temporal variability $(F=1.52, \mathrm{p}=0.29)$ were detected between P and Cs (Fig. 4D). Results of PERMDISP showed a significant $\mathrm{T} \times \mathrm{P}$ vs. Cs interaction at both investigated scales (replicates, $F=16.07[p=0.001]$; sites, $F=7.74[\mathrm{p}=0.001])$, indicating significant changes in spatial heterogeneity of assemblages through time. Post hoc pair-wise comparisons indicated a general increase through time of spatial heterogeneity in the control areas at both investigated spatial scales, with assemblages showing higher spatial heterogeneity compared to assemblages in the reserve (Fig. 5A).

Also in the subtidal, PERMANOVA showed significant differences in the multivariate structure of assemblages between the reserve and control areas, varying with time (Table 2 ). Significant variability at the scales of Site and Location varying with Time was also detected (see the $\mathrm{T} \times \mathrm{L}$ and $\mathrm{T} \times \mathrm{S}[\mathrm{L}]$ interactions in Table 2). The nMDS of $\mathrm{T} \times \mathrm{L}$ centroids seems to suggest consistent patterns of variation (Fig. 2B), with the control locations showing a great deal of separation from the reserve. A clearer picture is supplied by CAP analysis, showing that such differences in the structure of assemblages were due substantially to the decreasing contribution of macroalgae in shaping
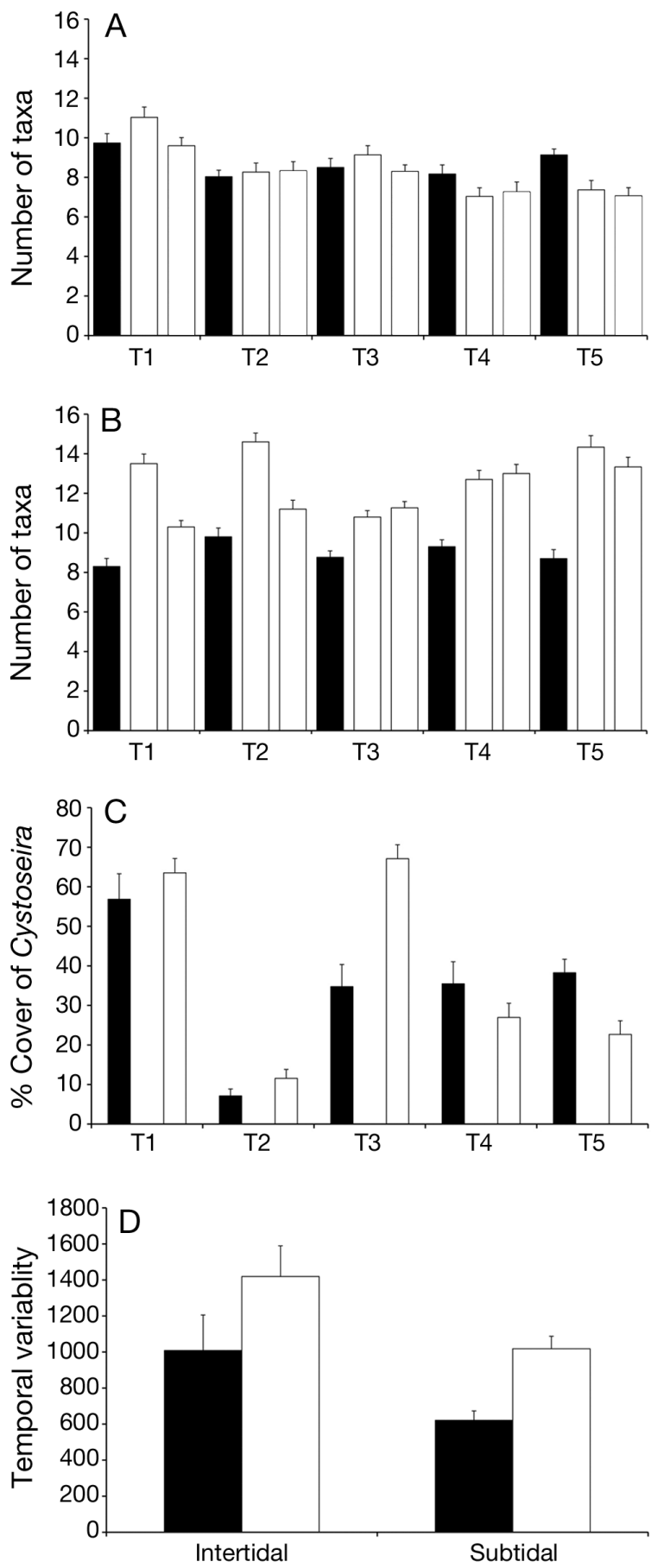

Fig. 4. Mean number of taxa $( \pm \mathrm{SE})$ observed respectively in (A) the intertidal and in (B) the shallow subtidal at each sampling date (Time 1 [T1] to Time 5 [T5]). (C) Mean percent cover $( \pm \mathrm{SE})$ of Cystoseira spp. canopy recorded during the whole period in the intertidal in the no-take and control locations (see details in 'Results') (T1 to T5). (D) Mean temporal stability (expressed as the mean PERMANOVA pseudovariance components associated with the factor Time- see 'Materials and methods') ( \pm SE) of intertidal and subtidal assemblages. Black bars: no-take locations; white bars: control locations 


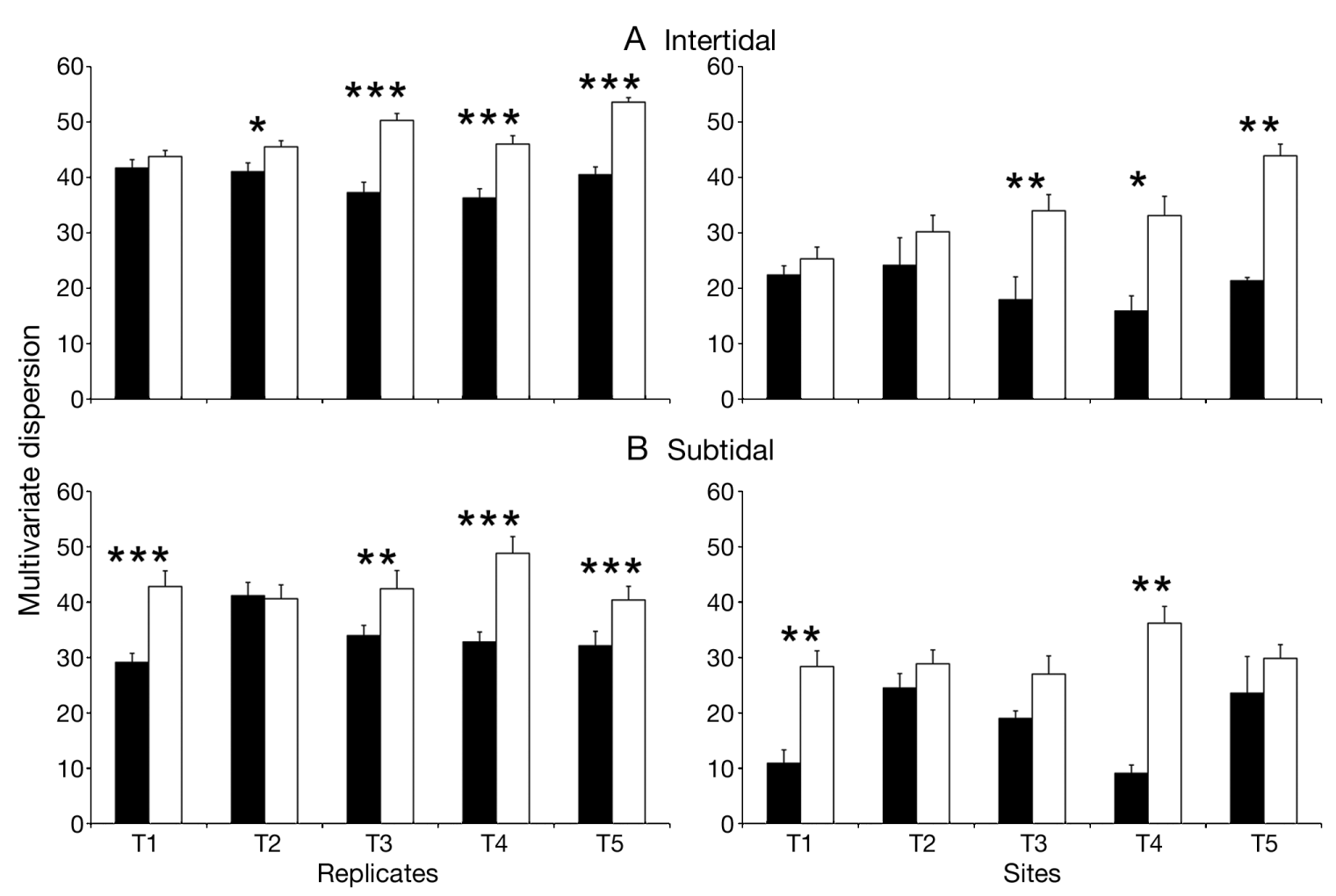

Fig. 5. Average $( \pm \mathrm{SE})$ multivariate dispersion based on dissimilarity matrices of $(\mathrm{A})$ intertidal and (B) subtidal assemblages at different spatial scales (replicates, sites) for Times 1 to 5 (T1 to T5). Black bars: no-take locations; white bars: control locations. ${ }^{*} \mathrm{p}<0.05_{i}{ }^{* *} \mathrm{p}<0.01 i^{* * *} \mathrm{p}<0.001$

the subtidal assemblages in the reserve area with respect to those in the controls (Fig. 3B). As for the intertidal, only CAP plots of Time 1 (2001) and Time 5 (2010) were reported (see Fig. S1B in the supplement for CAP plots of Times 2 to 4 ). At the end of the study period, assemblages in the reserve were structurally dominated by organisms typical of barren areas such as encrusting calcified rhodophytes (ECR), encrusting invertebrates like encrusting red sponges (ERS), and boring sponges belonging to the genus Cliona (Cli). Control areas were characterized by more complex 3dimensional assemblages, with a significantly higher number of taxa than found in the reserve area (Table 3, Fig. 4B), mostly represented by erect (Laurencia complex [Lau], Halimeda tuna [Htu], Peyssonnelia spp. [Pey]), canopy-forming (Dictyotales [Dic]), turf-forming (articulated corallines [AC], Amphiroa spp. [Amp], Corallina sp. [Cor], dark filamentous algae [DFA], Padina pavonica [Pad]) algae, massive dark sponges (MDS) and other invertebrates (Didemnidae [Did], hydroids [Hyd], Gastrochaena dubia [Gdu], encrusting bryozoans [EB]) (Fig. 3B).

ANOVA on estimates of multivariate temporal variability detected significant differences $(F=15.09, \mathrm{p}<$ 0.01 ) between the reserve and control areas, the latter showing higher values of temporal variability
(Fig. 4D). Results of PERMDISP showed a significant $\mathrm{T} \times \mathrm{P}$ vs. Cs interaction at both scales investigated (replicates, $F=15.46[\mathrm{p}=0.001]$; sites, $F=6.22[\mathrm{p}=$ $0.004]$ ), indicating that differences in spatial heterogeneity of assemblages between the reserve area and the controls varied in time. Even if a clear trend is not identifiable, post hoc pair-wise comparisons generally indicated significantly higher spatial heterogeneity of assemblages in the control areas than in the reserve, especially at the scale of replicates (Fig. 5B).

Phytoplanktonic PP significantly differed between $\mathrm{P}$ and $\mathrm{Cs}$, with control areas showing consistently higher values than the no-take zone $(\mathrm{p}<0.001)$. PP also showed significant temporal variability (see Fig. S2 and Table S1 in the supplement at www.intres.com/articles/suppl/m466p021.pdf).

\section{DISCUSSION}

Our results show that the contrasting effects of protection over benthic assemblages greatly depend on habitat features and are possibly driven by the limited enforcement combined with the isolation of the reserve. 
In the intertidal, significant differences between assemblages in the reserve and the controls were detected over time. Temporal variations suggested a trajectory of change exhibiting an increase in the cover of the canopy and in the invertebrate component of the understory assemblages associated with Cystoseira in the no-take-zone compared with an apparent degradation towards turf-dominated assemblages in control areas. Both in the NW Mediterranean and in the Adriatic Sea, Fucales has suffered a long-term decline in the last century due to a combination of direct and indirect human impacts (Thibaut et al. 2005, Serio et al. 2006, Hereu et al. 2008a, Perkol-Finkel \& Airoldi 2010). Sala et al. (2012) found a negative relationship between PP and the abundance of Fucales across the Mediterranean Sea, possibly resulting from a concurrent loss of Cystoseira in productive, but densely populated and developed coastlines and not from a direct association between algal canopies and PP.

Successful cases of recovery at the ecosystem level are rare in the Mediterranean. When occurring, they are often related to the presence of MPAs and, in a few cases, are associated with changes in benthic assemblages (Bevilacqua et al. 2006, Guidetti 2006, Libralato et al. 2010). An example of recovery of a Cystoseira canopy after protection comes from the Medes Islands Marine Reserve, where a significant increase of cover was detected about $15 \mathrm{yr}$ after the reserve was established and in Port-Cros National Park (Hereu et al. 2008a,b). In our case, the isolation of the no-take zone likely guaranteed mitigation from threats considered to be critical for the canopy, such as pollution, human trampling and coastal development (Mangialajo et al. 2008), maintaining the canopy and allowing positive effects on the associated invertebrate fauna. The presence of these pressures in the main group of islands is potentially conducive to slow regression of the Cystoseira canopy and the shift towards turf-forming algae, with a consequent decrease in assemblage structural complexity and biodiversity loss (Benedetti-Cecchi et al. 1999, 2001, Bulleri et al. 2002). Since dispersion of Cystoseira appears to be very limited, the recovery of lost canopies in large areas may prove difficult (Mangialajo et al. 2012) and management initiatives should be carefully planned to mitigate the effect of human activities.

Our analyses documented remarkable temporal stability of the subtidal benthic assemblages in the no-take zone, which, for at least $10 \mathrm{yr}$, were persistently characterized by organisms typical of barren grounds. The lack of apex predators (Sala et al.
2012), possibly linked to the lack of enforcement allowing illegal fishing practices, is a potential explanation. Predatory fishes can play a major role in determining the abundance of their prey, strongly modifying the ecosystem as a whole (Shears \& Babcock 2002). In the Mediterranean, these effects have been observed for sea urchins, which are the major benthic herbivores on rocky substrates (Sala et al. 1998). In absence of apex predators, subtidal assemblages in the no-take area are exposed to intense grazing pressure $\left(400 \mathrm{~g} \mathrm{~m}^{-2}\right.$ of the biomass reported for sea urchins in the reserve area; Sala et al. 2012). Isolation, combined with lack of enforcement, possibly further limits larval connectivity from upstream sources and could play a critical role in the persistence of barren substrates in subtidal habitat. Shanks et al. (2003) conclude that reserves spaced 10 to $20 \mathrm{~km}$ apart should be close enough to capture propagules released from adjacent reserves (or unprotected locations). The reserve considered here is $>20 \mathrm{~km}$ from the rest of the Archipelago (and $>40 \mathrm{~km}$ from the coast), and there is evidence that the oceanographic conditions of the whole area (Artegiani et al. 1997, Poulain 2001) may prevent any possibility of the reserve being sustained by outside sources of larvae and propagules, impairing the recovery of this low-biodiversity habitat (Kinlan \& Gaines 2003). Conservation priorities for the no-take zone do not include specific actions for habitat restoration. Quite intuitively, low diversity and productivity of degraded habitats, such as noted in barren grounds, are very unlikely to support the rebuilding of fish populations (Guidetti et al. 2004). Therefore, the isolation of the no-take zone is likely to lead to detrimental effects on the recovery of benthic assemblages, also impairing beneficial outcomes on fish.

In the subtidal, in control areas where fishing is allowed, however, more complex 3-dimensional assemblages have been found, with significantly higher numbers of taxa than those found in the reserve area. Other examples demonstrated that topdown mechanisms are not always the rule within MPAs, and cascading effects are likely to vary depending on local conditions and on the characteristics of the species that are locally dominant (Micheli et al. 2004, Hernández et al. 2008, Shears et al. 2008). Our results further reinforce the idea that factors other than fishing are largely responsible for the structure of benthic communities. The water-column features, for example, could be partially responsible for the observed patterns. The distribution and abundance of marine benthic communities are dependent on water-column processes, such as PP, affecting the 
transfer of organic material between benthic and pelagic systems (Hobson et al. 1995). Here, the higher diversity in subtidal benthic assemblages could also be triggered by the higher PP values in control areas compared to the no-take zone. A combination of natural (e.g. upwelling) and humandriven (e.g. sewage discharge, visiting vessels, urbanization) processes may influence the PP values documented in the main group of islands. However, further experimental studies are needed to ascertain the different roles of PP in structuring community assemblages and in recovery of subtidal versus intertidal habitat. Furthermore, we cannot exclude the influence of other factors on the structural changes of assemblages.

Increased variability in space and time has been considered an early warning indicator of stress in benthic assemblages (Hewitt et al. 2010, Bevilacqua et al. 2012, Guarnieri et al. 2012). The increased heterogeneity assessed both in the intertidal and in the subtidal assemblages at the end of the studied period may result from a concurrent increase in human activities occurring in the Archipelago. Few data are available to precisely quantify this growth. The mean annual number of tourists within and around the MPA was about 20000 in 2002, while 163154 tourists were counted in 2009. Also, the mean annual number of divers went from 2600 to about 5000 individual requests from 2007 to 2009. In the same period, the mean annual number of recreational fishers within the MPA went from 244 to 516 (data from the Management Direction). In the Mediterranean Sea, affected by a long history of humaninduced changes and shifting baselines, the lack of reliable historical records represents a major limitation for setting meaningful reference conditions that might assist in assessing recovery. Also, the effects of the environmental context can potentially further impair the long-term success of recovery at a given site (Hawkins et al. 2002). In the absence of data prior to MPA institution and without a systematic assessment of the intensity and distribution of pressures inside the MPA, it may be difficult to detect the causal processes involved in the observed patterns and, also, to decide upon possible restoration strategies. Legislation concerning the establishment of MPAs systematically underlines the importance of monitoring activities in order to assess whether the declared MPA objectives are achieved. However, such expectations are often undermined by insufficient post-implementation institutional support for monitoring (Davis 2005). Once MPAs have been established, management effectiveness is seldom adequately assessed (e.g. Benedetti-Cecchi et al. 2003, Gell \& Roberts 2003, Fraschetti et al. 2005, Carr et al. 2011) and long-term studies, such as the one reported here, have rarely been conducted.

Protection effects should be expected if adequate enforcement and compliance with MPA goals are guaranteed (Agardy et al. 2011). Placing marine reserves in putative de facto refuges may only provide supplementary protection against the effects of anthropogenic activities. The effectiveness of protection in true de facto refuges has mainly been related to fish assemblages (Gaines et al. 2010), but little is known about their utility in other ecological compartments, such as algal canopies and benthic assemblages. The effects of protection may be unevenly distributed among ecological compartments (O'Sullivan \& Emmerson 2011), or isolation may compromise larval supply (Johannesson 1988), with detrimental effects on species with limited dispersion and increased vulnerability to catastrophic disturbance events (Gaines et al. 2010).

Our findings showed that ineffective protection in small, isolated and unregulated MPAs could magnify the potential risk of the context-dependent effects of MPAs. Isolation, moreover, may be conducive to ecological drawbacks negatively affecting assemblages. Since isolation per se does not guarantee the exclusion of human activities and, by definition, may have critical effects on the connectivity of reserve networks, placing new MPAs in de facto refuges may only lead to limited benefits on biodiversity at a basin scale. The failure of unregulated putative de facto refuges to ensure comprehensive protection lies in the fact that isolation may mitigate specific human pressures, but not all, and that mitigation effects could be habitat specific.

Enforcement and compliance are fundamental aspects of effective MPAs, and the selection of remote areas without the appropriate support to avoid illegal activities is not sufficient to insure effective protection. A systematic analysis of the distribution and intensity of all activities allowed within MPAs is critical to increase the effectiveness of conservation actions and to provide complementary criteria for conservation priorities regarding alternative zoning and regulations. In addition, since limited funding impairs efficient enforcement, more costeffective methods may help in controlling the remote no-take zone, such as remote video-surveillance or involvement of the local community, volunteers and private funding (Game et al. 2009).

Much progress still remains to reduce the conflicts stemming from improper MPA designations (i.e. 
without accounting for human activities). Efficient conservation planning should be based on scientific criteria taking into account the human dimension (Fraschetti et al. 2009, Giakoumi et al. 2011). Implementing an ecosystem-based management approach (EBM) at regional or national scales within a network of connected MPAs is a potentially effective component and should represent a critical strategy to reverse the present trajectory of change, providing simultaneous benefits for the conservation of biodiversity and management of resources (Halpern et al. 2010, Agardy et al. 2011). On the other hand, it is unlikely that major improvements in marine environmental management will be possible without adequate financial support to put into practice the knowledge stemming from recent advances in conservation science (Knight et al. 2008).

Acknowledgements. This study was directly funded by the Italian Ministry of the Environment (Afrodite project). The research leading to these results also received funding from the European Community's 7th Framework Programme (FP7/2007-2013) under Grant Agreement No. 287844 for the project 'Towards COast to COast NETworks of marine protected areas (from the shore to the high and deep sea), coupled with sea-based wind energy potential (COCONET).' Support from the European Union (VECTORS, PERSEUS integrated projects) and Centro Euro-Mediterraneo per i Cambiamenti Climatici (CMCC) is also acknowledged. The Direction of the Isole Tremiti MPA provided research permits. Thanks to F. Gianni and N. Sales Enriquez for field support. MODIS data were provided courtesy of the Ocean Biology Products Group at NASA Goddard Space Flight Center. Pathfinder SST data were provided courtesy of NOAA National Oceanographic Data Center and the University of Miami.

\section{LITERATURE CITED}

Abdulla A, Gomei M, Maison E, Piante C (2008) Status of marine protected areas in the Mediterranean Sea. IUCN, Malaga and WWF, Paris

Agardy T, di Sciara GN, Christie P (2011) Mind the gap: Addressing the shortcomings of marine protected areas through large scale marine spatial planning. Mar Policy 35:226-232

Allison GW, Gaines SD, Lubchenco J, Possingham HP (2003) Ensuring persistence of marine reserves: Catastrophes require adopting an insurance factor. Ecol Appl 13:8-24

Anderson MJ (2001) Permutation tests for univariate or multivariate analysis of variance and regression. Can J Fish Aquat Sci 58:626-639

> Anderson MJ, Robinson J (2003) Generalized discriminant analysis based on distances. Aust NZ J Stat 45:301-318

Anderson MJ, Willis TJ (2003) Canonical analysis of principal coordinates: a useful method of constrained ordination for ecology. Ecology 84:511-525

Anderson MJ, Ellingsen KE, McArdle BH (2006) Multivari- ate dispersion as a measure of beta diversity. Ecol Lett 9: 683-693

Anderson MJ, Gorley RN, Clarke KR (2008) PERMANOVA+ for Primer: guide to software and statistical methods. PRIMER-E, Plymouth

Artegiani A, Bregant D, Paschini E, Pinardi N, Raicich F, Russo A (1997) The Adriatic Sea general circulation. 2. Baroclinic circulation structure. J Phys Oceanogr 27: 1515-1532

> Behrenfeld MJ, Falkowski PG (1997) Photosynthetic rates derived from satellite-based chlorophyll concentration. Limnol Oceanogr 42:1-20

Bellwood DR, Hughes TP, Folke C, Nyström M (2004) Confronting the coral reef crisis. Nature 429:827-833

> Benedetti-Cecchi L, Menconi M, Cinelli F (1999) Pre-emption of the substratum and the maintenance of spatial pattern on a rocky shore in the Northwest Mediterranean. Mar Ecol Prog Ser 181:13-23

Benedetti-Cecchi L, Pannacciulli F, Bulleri F, Moschella PS, Airoldi L, Relini G, Cinelli F (2001) Predicting the con«sequences of anthropogenic disturbance: large-scale effects of loss of canopy algae on rocky shores. Mar Ecol Prog Ser 214:137-150

Benedetti-Cecchi L, Bertocci I, Micheli F, Maggi E, Fosella T, Vaselli S (2003) Implications of spatial heterogeneity for management of marine protected areas (MPAs): examples from assemblages of rocky coasts in the Northwest Mediterranean. Mar Environ Res 55:429-458

Bevilacqua S, Terlizzi A, Fraschetti S, Russo GF, Boero F (2006) Mitigating human disturbance: Can protection influence trajectories of recovery in benthic assemblages? J Anim Ecol 75:908-920

> Bevilacqua S, Plicanti A, Sandulli R, Terlizzi A (2012) Measuring more of $\beta$-diversity: quantifying patterns of variation in assemblage heterogeneity. An insight from marine benthic assemblages. Ecol Indic 18:140-148

Bulleri F, Benedetti-Cecchi L, Acunto S, Cinelli F, Hawkins SJ (2002) The influence of canopy algae on vertical patterns of distribution of low-shore assemblages on rocky coasts in the Northwest Mediterranean. J Exp Mar Biol Ecol 267:89-106

- Carr MH, Woodson CB, Cheriton OM, Malone D, McManus MA, Raimondi PT (2011) Knowledge through partnerships: integrating marine protected area monitoring and ocean observing systems. Front Ecol Environ 9:342-350

Casey KS, Brandon TB, Cornillon P, Evans R (2010) The past, present and future of the AVHRR Pathfinder SST Program. In: Barale V, Gower JFR, Alberotanza L (eds) Oceanography from space: revisited: Springer, Heidelberg, p 272-288

CIESM (Commission Internationale pour l'Exploration Scientifique de la mer Mediterranee) (1999) Scientific design and monitoring of Mediterranean Marine Protected Areas: Porto Cesareo (Italy), 21-24 October 1999. Workshop Series No. 8, CIESM, Monaco

Clarke KR, Gorley RN (2006) PRIMER V6: user manual/tutorial. PRIMER-E, Plymouth

Claudet J, Fraschetti S (2010) Human-driven impacts on marine habitats: a regional meta-analysis in the Mediterranean Sea. Biol Conserv 143:2195-2206

> Claudet J, Osenberg CW, Benedetti-Cecchi L, Domenici P and others (2008) Marine reserves: Size and age do matter. Ecol Lett 11:481-489

- Claudet J, Osenberg CW, Domenici P, Badalamenti F and others (2010) Marine reserves: Fish life history and eco- 
logical traits matter. Ecol Appl 20:830-839

> Claudet J, Garcia-Charton JA, Lenfant P (2011) Combined effects of levels of protection and environmental variables at different spatial resolutions on fish assemblages in a marine protected area. Conserv Biol 25:105-114

Clemente S, Hernández JC, Brito A (2011) Context-dependent effects of marine protected areas on predatory interactions. Mar Ecol Prog Ser 437:119-133

Coma R, Ribesa M, Gili JM, Zabala M (2000) Seasonality in coastal benthic ecosystems. Trends Ecol Evol 15:448-453

Côté IM, Mosqueira I, Reynolds JD (2001) Effects of marine reserve characteristics on the protection of fish populations: a meta-analysis. J Fish Biol 59:178-189

> Davis GE (2005) Science and society: marine reserve design for the California channel islands. Conserv Biol 19: 1745-1751

> Dethier MN, Graham ES, Cohen S, Tear LM (1993) Visual versus random-point percent cover estimations: 'objective' is not always better. Mar Ecol Prog Ser 96:93-100

> Frank KT, Petrie B, Shackell NL, Choi JS (2006) Reconciling differences in trophic control in mid-latitude marine ecosystems. Ecol Lett 9:1096-1105

- Fraschetti S, Terlizzi A, Bussotti S, Guarnieri G, D'Ambrosio P, Boero F (2005) Conservation of Mediterranean seascapes: analyses of existing protection schemes. Mar Environ Res 59:309-332

Fraschetti S, D'Ambrosio P, Micheli F, Pizzolante F, Bussotti S, Terlizzi A (2009) Planning Marine Protected Areas in a human-dominated seascape. Mar Ecol Prog Ser 375: $13-24$

Fraschetti S, Claudet J, Grorud-Kolbert K (2011) Transitioning from single-sector management to ecosystem-based management: What can marine protected areas offer? In: Claudet J (ed) Marine Protected Areas-A multidisciplinary approach. Cambridge University Press, Cambridge, p 11-34

Gaines SD, Lester SE, Grorud-Colvert K, Costello C, Pollnac R (2010) Evolving science of marine reserves: new developments and emerging research frontiers. Proc Natl Acad Sci USA 107:18251-18255

- Game ET, Grantham HS, Hobday A, Pressey RL and others (2009) Pelagic protected areas: the missing dimension in ocean conservation. Trends Ecol Evol 24:360-369

Gell FR, Roberts CM (2003) Benefits beyond boundaries: the fishery effects of marine reserves. Trends Ecol Evol 18: 448-455

Giakoumi S, Grantham HS, Kokkoris GD, Possingham HP (2011) Designing a network of marine reserves in the Mediterranean Sea with limited socio-economic data. Biol Conserv 144:753-763

> Glasby TM (1997) Analysing data from post-impact studies using asymmetrical analyses of variance: a case study of epibiota on marinas. Aust J Ecol 22:448-459

Gorman D, Connell SD (2009) Recovering subtidal forests in human-dominated landscapes. J Appl Ecol 46: 1258-1265

Guarnieri G, Terlizzi A, Bevilacqua S, Fraschetti S (2012) Increasing heterogeneity of sensitive assemblages as a consequence of human impact in submarine caves. Mar Biol 159:1155-1164

> Guidetti P (2006) Marine reserves reestablish lost predatory interactions and cause community changes in rocky reefs. Ecol Appl 16:963-976

Guidetti P, Fraschetti S, Terlizzi A, Boero F (2004) Effects of desertification caused by Lithophaga lithophaga (Mol- lusca) fishery on littoral fish assemblages along Apulian rocky coasts of southeastern Italy. Conserv Biol 18: 1417-1423

Guidetti P, Milazzo M, Bussotti S, Molinari A and others (2008) Italian marine reserve effectiveness: Does enforcement matter? Biol Conserv 141:699-709

> Halpern BS (2003) The impact of marine reserves: Do reserves work and does reserve size matter? Ecol Appl 13:117-137

- Halpern BS, Warner RR (2002) Marine reserves have rapid and lasting effects. Ecol Lett 5:361-366

> Halpern BS, Walbridge S, Selkoe KA, Kappel CV and others (2008) A global map of human impact on marine ecosystems. Science 319:948-952

> Halpern BS, Lester SE, McLeod KL (2010) Placing marine protected areas onto the ecosystem-based management seascape. Proc Natl Acad Sci USA 107:18312-18317

Hawkins SJ, Allen JR, Ross PM, Genner MJ (2002) Marine and coastal ecosystems. In: Perrow MR, Davy AJ (eds) Handbook of ecological restoration, Vol 2. Cambridge University Press, Cambridge, p 121-148

- Hereu B, Mangialajo L, Ballesteros E, Thibaut T (2008a) On the occurrence, structure and distribution of deep-water Cystoseira (Phaeophyceae) populations in the Port-Cros National Park (north-western Mediterranean). Eur J Phycol 43:263-273

Hereu B, Zabala M, Sala E (2008b) Multiple controls of community structure and dynamics in a sublittoral marine environment. Ecology 89:3423-3435

> Hernández JC, Clemente S, Sangil C, Brito A (2008) Actual status of the sea urchin Diadema aff. antillarum populations and macroalgal cover in marine protected areas compared to a highly fished area (Canary Islands - eastern Atlantic Ocean). Aquat Conserv 18:1091-1108

> Hewitt J, Thrush S, Lohrer A, Townsend M (2010) A latent threat to biodiversity: consequences of small-scale heterogeneity loss. Biodivers Conserv 19:1315-1323

> Hobson KA, Ambrose WG, Renaud PE (1995) Sources of primary production, benthic-pelagic coupling, and trophic relationships within the Northeast Water Polynya: insights from delta ${ }^{13} \mathrm{C}$ and delta ${ }^{15} \mathrm{~N}$ analysis. Mar Ecol Prog Ser 128:1-10

> Hughes TP, Bellwood DR, Folke C, Steneck RS, Wilson J (2005) New paradigms for supporting the resilience of marine ecosystems. Trends Ecol Evol 20:380-386

> Jennings S (2000) Patterns and prediction of population recovery in marine reserves. Rev Fish Biol Fish 10: 209-231

Jennings S (2009) The role of marine protected areas in environmental management. ICES J Mar Sci 66:16-21

Johannesson K (1988) The paradox of Rockall: Why is a brooding gastropod (Littorina saxatilis) more widespread than one having a planktonic larval dispersal stage ( $L$. littorea)? Mar Biol 99:507-513

> Kaiser MJ (2005) Are marine protected areas a red herring or fisheries panacea? Can J Fish Aquat Sci 62:1194-1199

Kinlan BP, Gaines SD (2003) Propagule dispersal in marine and terrestrial environments: a community perspective. Ecology 84:2007-2020

> Knight AT, Cowling RM, Rouget M, Balmford A, Lombard AT, Campbell BM (2008) Knowing but not doing: selecting priority conservation areas and the research-implementation gap. Conserv Biol 22:610-617

Kruskal JB, Wish M (1978) Multidimensional scaling. Sage Publications, Beverly Hills, CA 
Lester SE, Halpern BS, Grorud-Colvert K, Lubchenco J and others (2009) Biological effects within no-take marine reserves: a global synthesis. Mar Ecol Prog Ser 384: 33-46

Libralato S, Coll M, Tempesta M, Santojanni A and others (2010) Food-web traits of protected and exploited areas of the Adriatic Sea. Biol Conserv 143:2182-2194

MacArthur RH, Wilson EO (1967) The theory of island biogeography. Princeton University Press, Princeton, NJ

Mangialajo L, Chiantore M, Cattaneo-Vietti R (2008) Loss of fucoid algae along a gradient of urbanisation, and structure of benthic assemblages. Mar Ecol Prog Ser 358: 63-74

Mangialajo L, Chiantore M, Susini ML, Meinesz A, Cattaneo-Vietti R and others (2012) Zonation patterns and interspecific relationships of fucoids in microtidal environments. J Exp Mar Biol Ecol 412:72-80

> McArdle BH, Anderson MJ (2001) Fitting multivariate models to community data: a comment on distance-based redundancy analysis. Ecology 82:290-297

McArdle BH, Anderson MJ (2004) Variance heterogeneity, transformations, and models of species abundance: a cautionary tale. Can J Fish Aquat Sci 61:1294-1302

McLeod E, Salm R, Green A, Almany J (2009) Designing marine protected area networks to address the impacts of climate change. Front Ecol Environ 7:362-370

Meese RJ, Tomich PA (1992) Dots on the rocks: a comparison of percent cover estimation methods. J Exp Mar Biol Ecol 165:59-73

Micheli F, Halpern BS, Botsford LW, Warner RR (2004) Trajectories and correlates of community change in no-take marine reserves. Ecol Appl 14:1709-1723

> Mora C, Sale PF (2011) Ongoing global biodiversity loss and the need to move beyond protected areas: a review of the technical and practical shortcomings of protected areas on land and sea. Mar Ecol Prog Ser 434:251-266

Mosquera I, Côté IM, Jennings S, Reynolds JD (2000) Conservation benefits of marine reserves for fish populations. Anim Conserv 3:321-332

Mumby PJ, Harborne AR (2010) Marine reserves enhance the recovery of corals on caribbean reefs. PLoS ONE 5: e8657

> O'Sullivan D, Emmerson M (2011) Marine reserve designation, trophic cascades and altered community dynamics. Mar Ecol Prog Ser 440:115-125

> Palumbi SR (2004) Marine reserves and ocean neighborhoods: the spatial scale of marine populations and their management. Annu Rev Environ Resour 29:31-68

Parravicini V, Rovere A, Vassallo P, Micheli F and others (2012) Understanding relationships between conflicting human uses and coastal ecosystems status: a geospatial modeling approach. Ecol Indic 19:253-263

> Perkol-Finkel S, Airoldi L (2010) Loss and recovery potential of marine habitats: an experimental study of factors maintaining resilience in subtidal algal forests at the Adriatic Sea. PLoS ONE 5:e10791

Poulain PM (2001) Adriatic Sea surface circulation as derived from drifter data between 1990 and 1999. J Mar Syst 29:3-32

Sala E, Boudouresque CF, Harmelin-Vivien M (1998) Fish- ing, trophic cascades, and the structure of algal assemblages: evaluation of an old but untested paradigm. Oikos 82:425-439

> Sala E, Aburto-Oropeza O, Paredes G, Parra I, Barrera JC, Dayton PK (2002) A general model for designing networks of marine reserves. Science 298:1991-1993

> Sala E, Ballesteros E, Dendrinos P, Di Franco A and others (2012) The structure of Mediterranean rocky reef ecosystems across environmental and human gradients, and conservation implications. PLoS ONE 7:e32742

Serio D, Alongi G, Catra M, Cormaci M, Furnari G (2006) Changes in the benthic algal flora of Linosa Island (Straits of Sicily, Mediterranean Sea). Bot Mar 49: 135-144

Shanks AL, Grantham BA, Carr MH (2003) Propagule dispersal distance and the size and spacing of marine reserves. Ecol Appl 13:159-169

Shears NT, Babcock RC (2002) Marine reserves demonstrate top-down control of community structure on temperate reefs. Oecologia 132:131-142

Shears NT, Babcock RC, Salomon AK (2008) Context dependent effects of fishing: variation in trophic cascades across environmental gradients. Ecol Appl 18: 1860-1873

Spalding MD, Fish L, Wood LJ (2008) Toward representative protection of the world's coasts and oceans - progress, gaps, and opportunities. Conserv Lett 1:217-226

> Steneck RS, Dethier MN (1994) A functional-group approach to the structure of algal-dominated communities. Oikos 69:476-498

Terlizzi A, Benedetti-Cecchi L, Bevilacqua S, Fraschetti S, Guidetti P, Anderson MJ (2005) Multivariate and univariate asymmetrical analyses in environmental impact assessment: a case study of Mediterranean subtidal sessile assemblages. Mar Ecol Prog Ser 289:27-42

- Terlizzi A, Felline S, Lionetto MG, Caricato R, Perfetti V, Cutignano A, Mollo E (2011) Detrimental physiological effects of the invasive alga Caulerpa racemosa on the Mediterranean white seabream Diplodus sargus. Aquat Biol 12:109-117

Terlizzi A, Tedesco P, Patarnello P (2012) Spread of pathogens from marine cage aquaculture - a potential threat for wild fish assemblages under protection regimes? In: Carvalho ED, David GS, Silva RJ (eds) Health and environment in aquaculture. InTech, New York, NY, p 403-414

Thibaut T, Pinedo S, Torras X, Ballesteros E (2005) Longterm decline of the populations of Fucales (Cystoseira spp. and Sargassum spp.) in the Alberes coast (France, North-western Mediterranean). Mar Pollut Bull 50: 1472-1489

> Villa F, Tunesi L, Agardy T (2002) Zoning marine protected areas through spatial multiple-criteria analysis: the case of the Asinara Island National Marine Reserve of Italy. Conserv Biol 16:515-526

> Wood LJ, Fish L, Laughren J, Pauly D (2008) Assessing progress towards global marine protection targets: shortfalls in information and action. Oryx 42:340-351

Worm B, Barbier EB, Beaumont N, Duffy JE and others (2006) Impacts of biodiversity loss on ocean ecosystem services. Science 314:787-790 